\title{
ANALISIS PELAKSANAAN PENATAUSAHAAN ASET TETAP PADA BPKAD KOTA PEKANBARU
}

\author{
Virna Museliza \\ Dosen Fakultas Ekonomi dan Ilmu Sosial \\ Universitas Islam Negeri Sulthan Syarif Kasim Riau \\ email:virna@uin-suska.ac.id
}

\begin{abstract}
Abstrak
Penelitian ini bertujuan untuk mengetahui Analisis Pelaksanaan Penatausahaan Aset Tetap Pada BPKAD Kota Pekanbaru dan kendala dalam Pelaksanaannya. Jenis penelitian deskriptif dengan pendekatan kualitatif. Tehnik pengumpulan data dengan observasi, wawancara dan dokumentasi. Hasil penelitian menunjukan ada 3 (tiga) Pelaksanaan Penatausahaan yaitu Pembukuan, Inventarisasi dan Pelaporan. Pada Pembukuan dan Pelaporan sudah terlaksana dengan baik tetapi Inventarisasi belum terlaksana dengan baik karena tidak adanya pembuktian kertas kerja pada setiap aset. Dinas Pendidikan adalah SKPD yang memiliki Aset yang terbanyak sehingga terlambat menyelesaikan laporan inventarisasinya karena belum selesainya setiap sekolah melakukan inventarisasi dan belum melaporkannya ke Dinas Pendidikan laporan inventarisasi itulah yang sering terlambat karena mindset menginventarisasi aset yang belum tinggi. Neraca sudah balance tapi pembuktian kertas kerja yang tidak bisa dibuktikan. Kendala dalam Pelaksanaan Penatausahaan Aset Tetap Pada BPKAD Kota Pekanbaru yaitu pertama, Sumber Daya Manusia yang tidak sesuai antara beban kerja dengan jumlah sumber daya manusia dan kurangnya sumber daya manusia yang memiliki keahlian di bidang pengelolaan aset, kedua Tekhnologi yang masih manual dengan menggunakan exsel, ketiga Keterbatasan waktu pelaksanaan inventarisasi yang hanya efektif selama 6 (enam) bulan yang dirasakan kurang maksimal. keempat, Dokumen Pendukung yang belum dapat dibutikan dan kelima Komitmen Pimpinan yang selalu komit tetap melaksanakan inventarisasi setiap tahunnya disertai dengan bukti kertas kerja dan sesuai antara laporan, neraca dan fisik.
\end{abstract}

\section{Kata Kunci : Aset Tetap, Pembukuan, Inventarisasi dan Pelaporan}

\section{PENDAHULUAN}

Aset tetap merupakan salah satu unsur yang harus dikelola dengan baik agar menghasilkan informasi yang andal dalam laporan keuangan daerah. Pengelolaan aset tetap merupakan upaya peningkatan efisiensi, efektivitas dan menciptakan nilai tambah dalam mengelola aset, menjadi modal awal bagi pemerintah daerah untuk melakukan pengembangan kemampuan keuangannya serta dapat menunjang peran dan fungsi pemerintah daerah sebagai pelayanan publik kepada masyarakat.

Dalam rangka pengamanan barang milik daerah dibutuhkan sistim penatausahaan yang dapat menciptakan pengendalian atas barang milik daerah.
Selain berfungsi sebagai alat kontrol, sistim penatausahaan juga harus memenuhi kebutuhan manajemen pemerintah di dalam perencanaan, pengadaan, pemeliharaan maupun penghapusan. Dengan langkah inventarisasi dan penilaian barang milik daerah tersebut, diproyeksikan kedepan akan dapat terwujud database barang milik daerah yang akurat, sehingga dapat dipergunakan bagi kepentingan penyusunan rencana kebutuhan dan penganggaran atas belanja barang dan/atau belanja modal pada Lembaga Negara.

Menurut Peraturan Menteri Dalam Negeri Nomor 19 Tahun 2016, Penatausahaan adalah rangkaian kegiatan yang meliputi pembukuan, inventarisasi, 
dan pelaporan barang milik daerah sesuai dengan ketentuan yang berlaku. Fenomena yang terjadi di Pemerintahan Kota Pekanbaru yaitu Pemerintah Kota Pekanbaru tahun 2008 dapat memperoleh opini Wajar Tampa Pengecualian (WTP). Namun setelah itu, sejak tahun 2009 hingga sekarang opini BPK RI terhadap validitas laporan keuangan pemerintah kota Pekanbaru turun menjadi Wajar Dengan Pengecualian (WDP) dengan point "pengelolaan aset" yang menjadi salah satu permasalahan dan kendala yang dihadapi. Oleh karena itu, Pemerintah Kota Pekanbaru melalui BPKAD pada tahun 2014 melakukan inventarisasi menyeluruh terhadap aset atau barang milik daerah kota
Pekanbaru dengan mengerahkan tim pelaksana pada masing-masing SKPD. Dari total 44 SKPD pada Pemerintah Kota Pekanbaru Tahun 2014, tersisa 3 SKPD yang masih mempunyai catatan dari hasil audit BPK RI. "Adapun 3 (tiga) SKPD yang dimaksud adalah Dinas Pendidikan, Dinas Kesehatan, Sekretariat Daerah Secara umum, kendala-kendala yang menyebabkan SKPD dimaksud belum dapat menyelesaikan inventarisasi adalah keterbatasan waktu pelaksanaan inventarisasi terhitung hanya efektif selama 6 bulan pada tahun 2014, dan minimnya (ketiadaan) dokumen pendukung dalam hal pencatatan aset selama ini (banyak dokumen aset yang belum ditemukan).

Tabel 1.

Daftar Aset Tetap Pemerintah Kota Pekanbaru

\begin{tabular}{|c|c|c|}
\hline No. & Jenis Aset & Nilai Aset \\
\hline 1. & Tanah & Rp 1.269.920.663.451,00,- \\
\hline 2. & Peralatan dan Mesin & Rp $\quad 583.481 .208 .767,00,-$ \\
\hline 3. & Gedung dan Bangunan & Rp 1.090.951.560.584,72,- \\
\hline 4. & Jalan, Irigasi dan Jaringan & Rp 3.302.888.725.955,00,- \\
\hline 5. & Aset Tetap Lainnya & $\mathrm{Rp} \quad 40.809 .660 .002,00,-$ \\
\hline 6. & Kontruksi Dalam Pengerjaan & $\operatorname{Rp} \quad 480.216 .832 .772,00,-$ \\
\hline Tota & Aset Tetap sampai Tahun 2015 & Rp 6.247.242.158.757,00,- \\
\hline
\end{tabular}

Sumber : BPKAD Kota Pekanbaru

Dari tabel 1. tentang Daftar Aset Tetap Pemerintah Kota Pekanbaru dapat dilihat Aset yang nilainya terbesar adalah aset jalan, irigasi dan jaringan yaitu

Tabel 2.

Daftar Aset Tetap Dinas Pendidikan Kota Pekanbaru

\begin{tabular}{cllr}
\hline No. & \multicolumn{1}{c}{ Jenis Aset } & \multicolumn{1}{c}{ Nilai Aset } \\
\hline 1. & Tanah & $\mathrm{Rp}$ & $434.007 .207 .145,00,-$ \\
2. & Peralatan dan Mesin & $\mathrm{Rp}$ & $147.201 .922 .416,71,-$ \\
3. & Gedung dan Bangunan & $\mathrm{Rp}$ & $562.183 .392 .541,72,-$ \\
4. Jalan, Irigasi dan Jaringan & $\mathrm{Rp}$ & $6.920 .905 .137,00,-$ \\
5. Aset Tetap Lainnya & $\mathrm{Rp}$ & $26.565 .565 .177,60,-$ \\
6. Kontruksi Dalam Pengerjaan & $\mathrm{Rp}$ & $69.665 .959 .897,00,-$ \\
Total Aset Tetap sampai Tahun 2016 & Rp1. 246.544.952.315,03,- \\
\hline \multicolumn{3}{c}{ Sumber : Dinas Pendidikan Kota Pekanbaru }
\end{tabular}

Dari tabel 2 di atas dapat dilihat gedung dan bangunan merupakan nilai aset yang tertinggi yaitu $\mathrm{Rp}$. 562.183.392.541,72,- dan yang terendah yaitu jalan Rp 6.920.905.137,00,- .
Rp.3.302.888.725.955,- sedangkan aset yang nilainya paling rendah adalah aset tetap lainnya Rp. 40.809.660.002,- 
Tabel 3. Daftar Aset Tetap Gedung dan Bangunan Dinas Pendidikan Kota Pekanbaru

\begin{tabular}{|c|c|c|c|}
\hline No. & \multicolumn{2}{|c|}{$\begin{array}{c}\text { Jenis Aset Tetap Gedung } \\
\text { dan Bangunan }\end{array}$} & $\begin{array}{l}\text { Jumlah } \\
\text { Aset }\end{array}$ \\
\hline 1. & $\begin{array}{l}\text { Gedung dan } \\
\text { Sekolah TK }\end{array}$ & Bangunan & 3 \\
\hline 2. & $\begin{array}{l}\text { Gedung dan } \\
\text { Sekolah SD }\end{array}$ & Bangunan & 194 \\
\hline 3. & $\begin{array}{l}\text { Gedung dan } \\
\text { Sekolah SMP }\end{array}$ & Bangunan & 40 \\
\hline 4. & $\begin{array}{l}\text { Gedung dan } \\
\text { Sekolah SMA }\end{array}$ & Bangunan & 16 \\
\hline 5. & $\begin{array}{l}\text { Gedung dan } \\
\text { Sekolah SMK }\end{array}$ & Bangunan & 7 \\
\hline 6. & $\begin{array}{l}\text { Gedung dan } \\
\text { Sanggar kesenial }\end{array}$ & $\begin{array}{l}\text { Bangunan } \\
\text { Budaya }\end{array}$ & 2 \\
\hline 7. & $\begin{array}{l}\text { Gedung dan } \\
\text { UPTD }\end{array}$ & Bangunan & 10 \\
\hline
\end{tabular}

Total Aset Tetap sampai Tahun 272 2016

Sumber: Dinas Pendidikan Kota

Pekanbaru

Barang milik Pemerintah Kota Pekanbaru dalam kerangka penyelenggaraan Pemerintahan Kota setiap tahunnya secara kuantitatif dan kualitatif memang terus meningkat baik dalam penyelenggaraan Pemerintahan, Pembangunan dan Kemasyarakatan. Dengan demikian, diperlukan kebijakan dan langkah yang terkoordinasi serta terpadu mengenai Pengelolaan Barang Milik Daerah oleh Pemerintah Kota Pekanbaru.

Dari uraian di atas penulis tertarik untuk melakukan penelitian tentang "Analisis Pelaksanaan Penatausahaan Aset Tetap Pada BPKAD Kota Pekanbaru" Rumusan Masalah

Dari latar belakang permasalahan penelitian, peneliti merasa perlu merumuskan permasalahan tersebut dengan rumusan masalah adalah sebagai berikut :
1. Bagaimana Analisis Pelaksanaan Penatausahaan Aset Tetap Pada BPKAD Kota Pekanbaru?

2. Apa saja kendala dalam Pelaksanaan Penatausahaan Aset Tetap Pada BPKAD Kota Pekanbaru?

\section{Tujuan Penelitian}

1. Untuk mengetahui Analisis Pelaksanaan Penatausahaan Aset Tetap Pada BPKAD Kota Pekanbaru;

2. Untuk mengetahui kendala dalam Pelaksanaan Penatausahaan Aset Tetap Pada BPKAD Kota Pekanbaru.

\section{TINJAUAN PUSTAKA \\ 2.1. Penatausahaan}

Menurut Peraturan Menteri Dalam Negeri Nomor 19 Tahun 2016 tentang Penatausahaan adalah rangkaian kegiatan yang meliputi pembukuan, inventarisasi, dan pelaporan barang milik daerah sesuai dengan ketentuan yang berlaku.

\subsection{Aset Tetap}

Definisi aset tetap menurut PP No.71 Tahun 2010 tentang Standar Akuntansi Pemerintah adalah aset berwujud yang mempunyai masa manfaat lebih dari 12 (dua belas) bulan untuk digunakan, atau dimaksudkan untuk digunakan, dalam kegiatan pemerintah atau dimanfaatkan oleh masyarakat umum.

\subsection{Penatausahaan Aset Tetap}

Penatausahaan berdasarkan Permendagri No. 19 Tahun 2016 mengatur mengenai kewajiban dan tanggungjawab Pengelola dan Kepala SKPD sebagai Pengguna dalam pelaksanaan pendaftaran, pencatatan, pembukuan, inventarisasi dengan cara sensus barang daerah, cara pembuatan Buku Inventaris dan Buku Induk Inventaris dan pembuatan Kartu Inventaris Ruangan dan Kartu Inventaris Barang serta sistem pelaporan.

\subsection{Penggolongan Barang Milik Daerah}

Barang milik daerah digolongkan ke dalam 6 (enam) kelompok yaitu:

1. Tanah;

2. Peralatan dan Mesin;

3. Gedung dan bangunan;

4. Jalan, irigasi dan jaringan;

5. Aset tetap lainnya;

6. Kontruksi dalam pengerjaan.

2.5. Pelaksanaan Sensus Barang Daerah 
Untuk mendapatkan data barang yang benar dan dapat dipertanggung jawabkan secara akurat (up to date), harus melalui sensus barang daerah. Barang yang akan di sensus adalah seluruh barang milik Pemerintah yang dapat dikelompokkan sebagai berikut :

1. Barang milik daerah (Provinsi dan Kabupaten/Kota). Termasuk barang yang dipisahkan pada Perusahaan Daerah/Badan Usah Milik Daerah/Yayasan Milik Daerah;

2. Barang milik/kekayaan Negara yang dipergunakan oleh Pemerintah daerah.

\subsection{Pengelolaan Barang Milik Daerah}

Peraturan Menteri dalam Negeri Republik Indonesia Nomor 19 Tahun 2016 Pengelolaan Barang Milik Daerah adalah keseluruhan kegiatan yang meliputi perencanaan kebutuhan dan penganggaran, pengadaan, penggunaan, pemanfaatan, pengamanan dan pemeliharaan, penilaian, pemindahtanganan, pemusnahan, penghapusan, penausahaan dan pembinaan, pengawasan dan pengendalian

\subsection{Pandangan Islam}

Hak milik Negara pada dasarnya juga merupakan hak milik umum, tetapi hak pengelolaannya menjadi wewenang pemerintah. Sebagaimana dalam firman Allah SWT dalam Jenis harta ini dijelaskan dalam hadith nabi yang berkaitan dengan sarana umum:

$$
\text { الْمُسْلِمُونَ شُرَكَاءُ فِيْ ثَلَاثِ فِي الْكَكَاِ وَالْمَاءِ وَالنَّارِ }
$$

Artinya:

"Manusia berserikat (bersama-sama memiliki) dalam tiga hal: air, padang rumput dan api" (HR Ahmad dan Abu Dawud) dan dalam hadith lain terdapat tambahan: "...dan harganya haram" (HR Ibn Majah dari Ibn Abbas).

\subsection{Kerangka Berpikir}

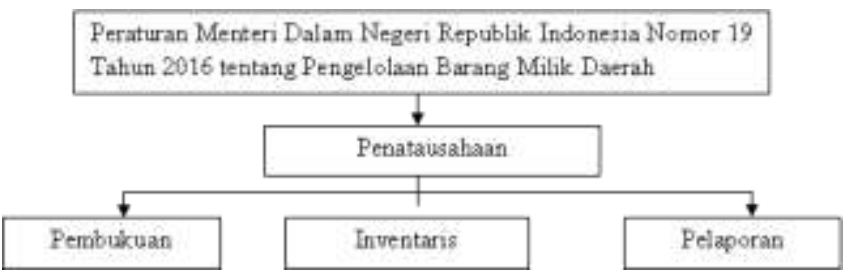

Gambar 1. Kerangka Berpikir
Berdasarkan kerangka berpikir pada gambar 1 dirumuskan konsep sebagai berikut :

1. Penatausahaan adalah rangkaian kegiatan yang meliputi pembukuan, inventarisasi, dan pelaporan barang milik daerah sesuai dengan ketentuan yang berlaku;

2. Aset Tetap adalah aset berwujud yang mempunyai masa manfaat lebih dari 12 (dua belas) bulan untuk digunakan dalam kegiatan pemerintah atau dimanfaatkan oleh masyarakat umum;

3. Pembukuan adalah proses pencatatan barang milik daerah kedalam daftar barang pengguna dan kedalam kartu inventaris barang serta dalam daftar barang milik daerah yang berrti :

a) Pengelola Barang harus melakukan pendaftaran dan pencatatan barang milik daerah yang berada di bawah penguasaannya ke dalam Daftar Barang Pengelola menurut penggolongan dan kodefikasi barang;

b) Pengguna Barang/Kuasa Pengguna Barang harus melakukan pendaftaran dan pencatatan barang milik daerah yang status penggunaannya berada pada Pengguna Barang/Kuasa Pengguna Barang ke dalam Daftar Barang Pengguna/Daftar Barang Kuasa Pengguna menurut penggolongan dan kodefikasi barang;

c) Pengelola Barang menghimpun daftar barang Pengguna/daftar barang Kuasa Pengguna menurut penggolongan dan kodefikasi;

d) Pengelola Barang menyusun daftar barang milik daerah berdasarkan himpunan daftar barang Pengguna/daftar barang Kuasa Pengguna dan daftar barang Pengelola menurut penggolongan dan kodefikasi barang;

e) Dalam daftar barang milik daerah termasuk barang milik daerah yang dimanfaatkan oleh pihak lain.

4. Inventarisasi merupakan kegiatan atau tindakan untuk melakukan perhitungan, 
pengurusan, penyelenggaraan, pengaturan, pencatatan data dan pelaporan barang milik daerah dalam unit pemakaian; yang berarti :

a) Pengguna Barang melakukan inventarisasi barang milik daerah paling sedikit 1 (satu) kali dalam 5 (lima) tahun;

b) Dalam hal barang milik daerah berupa persediaan dan konstruksi dalam pengerjaan, inventarisasi dilakukan oleh Pengguna Barang setiap tahun;

c) Pengguna Barang menyampaikan laporan hasil Inventarisasi kepada Pengelola Barang paling lama 3 (tiga) bulan setelah selesainya Inventarisasi;

d) Pengelola Barang melakukan inventarisasi barang milik daerah berupa tanah dan/atau bangunan yang berada dalam penguasaannya paling sedikit 1 (satu) kali dalam 5 (lima) tahun.

5. Pelaporan adalah proses penyusunan laporan barang semester dan setiap tahun setelah dilakukan inventarisasi dan pencatatan. Yang berarti :

a) Kuasa Pengguna Barang harus menyusun laporan barang Kuasa Pengguna Semesteran dan laporan barang Kuasa Pengguna Tahunan untuk disampaikan kepada Pengguna Barang;

b) Pengguna Barang menghimpun laporan barang Kuasa Pengguna Semesteran dan Tahunan sebagai bahan penyusunan laporan barang Pengguna semesteran dan tahunan;

c) Laporan barang Pengguna digunakan sebagai bahan untuk menyusun neraca SKPD untuk disampaikan kepada Pengelola barang;

d) Pengelola Barang harus menyusun laporan barang Pengelola semesteran dan laporan barang Pengelola tahunan;

e) Pengelola Barang harus menghimpun laporan barang Pengguna semesteran dan laporan barang Pengguna tahunan disertai laporan barang
Pengelola sebagai bahan penyusunan laporan barang milik daerah;

f) Laporan barang milik daerah digunakan sebagai bahan untuk menyusun neraca pemerintah daerah.

\section{METODOLOGI}

Penelitian ini berjenis penelitian deskrtiptif kualitatif. Lokasi penelitian Pada BPKAD Kota Pekanbaru. Tehnik pengumpulan data dengan observasi, wawancara dan dokumentasi. Informan dalam penelitian ini adalah kepala BPKAD, Kepala bidang aset BPKAD, Sub Bidang Analisis Pengadaan Aset BPKAD, Sub Bidang Inventarisasi dan Pemanfaatan Aset Proses BPKAD dan Kepala Bagian Pengelolaan Aset Dinas Pendidikan Kota Pekanbaru. Analisis data dimulai dari pengumpulan data, reduksi data, penyajian data dan penarikan kesimpulan.

\section{HASIL PENELITIAN DAN PEMBAHASAN \\ 4.1. Pelaksanaan Penatausahaan Aset Tetap Pada BPKAD Kota Pekanbaru}

Penelitian ini dilakukan di Badan Pengelolaan Keuangan dan Aset Daerah (BPKAD) Kota Pekanbaru dan Dinas Pendidikan sebagai salah satu SKPD yang belum selesai melaksanakan inventarisasi Barang Milik Daerah.

Hasil Wawancara dengan Bapak Ir Dino Prima sebagai Kepala Bidang Aset tentang mengapa Dinas Pendidikan belum selesai melaksanakan inventarisasi sesuai dengan jadwal yang telah ditentukan ? maka jawaban hasil wawancaranya adalah karena Dinas Pendidikan sebagai salah satu SKPD yang mempunyai aset paling banyak belum selesai melaksanakan inventarisasi disebabkan sebagian aset tidak bisa dibuktikan dengan pembuktian kertas kerja walaupun laporan neraca sudah sesuai dan Dinas Pendidikan diberikan batas akhir pelaksanaan inventarisasi pada bulan Desember 2016.

Kemudian keterangan dari Bapak Z. Bastian selaku Kepala Bagian Pengelolaan 
Aset Dinas Pendidikan Kota Pekanbaru adalah Inventarisasi belum selesai dilaksanakan di Dinas Pendidikan karena begitu banyaknya aset yang harus diinventarisasi yaitu terdiri dari Gedung Sekolah TK 3 gedung, Gedung Sekolah SD 194 gedung, Gedung Sekolah SMP 40 gedung, Gedung Sekolah SMA 16 gedung, Gedung Sekolah SMK 7 gedung, Gedung SKB 2 Gedung serta 10 UPTD. setiap sekolah melaksanakan inventarisasi kemudian dilaporkan ke bagian penatausahaan, laporan setiap sekolah itulah yang terlambat. Aset yang masuk dari APBD Provinsi Riau dan dari Pusat melalui APBN belum didaftarkan ke dinas kota.

Keterangan dari bapak Z. Bastian sebagai Kepala Bagian Pengelolaan Aset Dinas Pendidikan Kota Pekanbaru bahwa Dinas Pendidikan Kota Pekanbaru menerima berita acara serah terima dari BPKAD Kota Pekanbaru berupa daftar aset yang akan disampaikan kepada setiap sekolah. Setelah setiap sekolah menerima daftar aset dan sekolah langsung melaksanakan pembukuan. Dalam dokumen pelaksanaan ada kegiatan belanja modal dan belanja barang/jasa yang dilaksanakan oleh bidang sarana dan prasarana Dinas pendidikan. Bidang sarana dan prasarana yang melaksanakan kegiatan di tahun 2015 setelah aset diterima dilaporkan ke bagian penatausahaan aset langsung dicatat dan setiap sekolah melaksanakan inventarisasi kemudian dilaporkan ke bagian penatausahaan laporan, laporan setiap sekolah itulah yang terlambat karena mindset yang belum tinggi, aset yang masuk dari APBD Provinsi Riau dan dari Pemerintahan Pusat melalui APBN belum didaftarkan ke dinas.

Selain itu pengelola Barang harus melakukan pendaftaran dan pencatatan barang milik daerah yang berada di bawah penguasaannya ke dalam Daftar Barang Pengelola menurut penggolongan dan kodefikasi barang. Inventarisasi dilakukan secara sensus, sensus yang resmi dilaksanakan 1 (satu) kali dalam 5 (lima) tahun akan tetapi karena banyaknya aset pemerintah kota yang bermasalah maka walikota mengadakan program sensus yang tidak resmi yang dilaksanakan satu kali dalam satu tahun berdasarkan keterangan informan Devino Efka,SH,M.Si. Sub Bidang Analisis Aset. Dalam Pelaksanaan Sensus/Inventarisasi barang, yang bertanggung jawab penuh dalam pelaksanaannya adalah masing-masing Pengguna BMD. Sedangkan Pengelola terlibat selaku Pembina Tim Inventarisasi BMD. Untuk barang persediaan, pengguna barang berkewajiban melakukan stock opname setiap tahunnya. Untuk kontruksi dalam pengerjaan, pengguna barang akan melakukan update/merubah menjadi aset tetap golongan $\mathrm{C}$ atau D jika kontruksi dalam pengerjaan yang dimaksud telah selesai pelaksanaannya berdasarkan keterangan E.Zikra Habibah, SP, M.Si. Sub Bidang Inventarisasi dan Pemanfaatan Aset.

Data sekunder yang diberikan oleh E.Zikra Habibah, SP, M.Si sebagai Sub Bidang Invetarisasi dan pemanfaatan Aset BPKAD Kota Pekanbaru tentang

a. Tim Pelaksana Inventarisasi bertugas :

1. Menyediakan dan menyerahkan data BMD di unit kerja masing-masing kepada Tim Pusat Inventarsisasi untuk dilakukan sinkronisasi;

2. Mengikuti sosialisasi mekanisme pelaksanaan inventarisasi;

3. Petugas inventarisasi di UPTD, Kelurahan, Sekolah dan puskesmas melaksanakan inventarisasi di unit kerja masing-masing berdasarkan data BMD hasil Sinkronisasi dan menyerahkan Hardcopy dan Softcopy Hasil Inventarisasi kepada Pembantu Pengurus Barang di UPTD atasnya, setelah ditanda tangani Kepala Unit Kerja masing-masing, bersama Berita Acar Inventarisasi dan Surat Pernyataan;

4. Pembantu Pengurus Barang di UPTD melaksanakan inventarisasi di unit kerja masing-masing berdasarkan 
data BMD hasil Sinkronisasi dan mengkompilasi hasil;

5. Inventarisasi di unitnya dengan hasil inventarisasi unit kerja bawahnya (Sekolah/Puskesmas). Selanjutnya menyerahkan Hardcopy dan Softcopy Hasil Inventarisasi kepada Pengurus Barang di SKPD atasnya, setelah ditanda tangani Kepala Unit Kerja masing-masing, bersama Berita Acara Inventarisasi di lingkup UPTD bersangkutan;

6. Penyimpanan dan Pengurus Barang di SKPD melaksanakan inventarisasi di unit kerja masing-masing berdasarkan data BMD hasil Sinkronisasi dan mengkompilasi hasil inventarisasi di unit kerjanya bawahnya (UPTD). Selanjutnya menyerahkan Hardcopy dan Softcopy Hasil Inventarisasi dan unit kerjanya sendiri kepada Tim Pusat Inventarisasi, setelah ditanda tangani kepala SKPD masing-masing, bersama Berita Acara Inventarisasi, Surat Pernyataan dan Kompilasi Hasil Inventarisasi di lingkup SKPD bersangkutan.

b. Tugas Tim Pusat Inventaris bertugas :

1. Menyelenggarakan rapat koordinasi di tingkat tim pusat inventarisasi bersama tim fasilitator (tim pendamping);

2. Menyelenggarakan rapat teknis bersama tim pelaksana dan tim fasilitator (tim pendamping);

3. Melaksanakan sinkronisasi data aset tetap menurut laporan keuangan audited sampai dengan tahun 2013 dari bagian keuangan dengan data aset tetap menurut hasil inventarisasi;

4. Melaksanakan ekspose hasil sinkronisasi data aset tetap bersama Badan Pengelola Keuangan dan Aset Daerah Kota Pekanbaru dan Tim fasilitator (tim pendamping);

5. Melakukan konsultasi hasil sinkronisasi data aset tetap kepada BPK RI Perwakilan Provinsi Riau bersama tim fasilitator (tim pendamping);

6. Menyelenggarakan sosialisasi mekanisme pelaksanaan inventarisasi.

7. Melaksanakan supervisi pelaksanaan inventarisasi oleh Tim Pelaksana bersama Tim fasilitator (tim pendamping);

8. Mengumpulkan Hardcopy dan Softcopy Hasil Inventarisasi di tingkat SKPD beserta unit kerja dibawahnya dan melaksanakan kompilasinya didampingi Tim fasilitator (tim pendamping);

9. Menyerahkan dan menerima kembali secara bertahap hasil inventarisasi yang telah dikompilasi kepada Tim Penilai untuk mendapatkan nilai atas barang yang belum dilengkapi dengan nilai;

10. Melaksanakan pengolahan Data Final Hasil Inventarisasi untuk menjadi Buku Induk Inventaris Pemerintah Kota Pekanbaru;

11. Menyusun Draft SK Walikota Pekanbaru untuk Penetapan Hasil Inventarisasi BMD.

Kegiatan Pelaporan yang merupakan proses penyusunan laporan barang semester dan setiap tahun setelah dilakukan inventarisasi dan pencatatan. Adapun kegiatan pelaporan dilakukan mulai dari Kuasa Pengguna Barang di Pemerintahan adalah Kepala Dinas dan di Pemerintahan ada UPTD atau Badan Layanan Umum Daerah (BLUD) dianggap Kuasa Pengguna Barangnya adalah Kepala Dinas Misalnya Puskesmas menjadi Kuasa pengguna barang setiap semester BLUD harus melapor kepada kepala dinas Puskesmas setelah itu Kepala Dinas Puskesmas melapor kepada Sekretariat Daerah (SEKDA). (Devino Efka,SH,M.Si. Sub Bidang Analisis Aset). Pelaporan aset pada Dinas Pendidikan dilaporkan setiap tahun sekali (Z.Bastian, Kepala Bagian Pengelolaan Aset Dinas Pendidikan Kota Pekanbaru). 
Data sekunder yang diberikan oleh E.Zikra Habibah, SP, M.Si sebagai Sub Bidang Invetarisasi dan pemanfaatan Aset BPKAD Kota Pekanbaru tentang bentuk laporan hasil inventarisasi kepada pengelola adalah :

1. Tim Pusat Inventarisasi melaksanakan pengolahan Data Final Hasil Inventarisasi untuk menjadi Buku Induk Inventaris Pemerintah Kota Pekanbaru;

2. Melaksanakan ekspose Buku Induk Inventaris;

3. Mengkonsultasikan Buku Induk Inventaris Pemerintah Kota Pekanbaru kepada BPK RI Perwakilan Provinsi Riau;

4. Melaksanakan ekspose akhir dengan Sekretaris Daerah dan Kepala Perwakilan BPKP Provinsi Riau sebagai laporan inventarisasi untuk selanjutnya dapat ditetapkan dalam SK Walikota Pekanbaru sebagai Penetapan Hasil Inventarisasi BMD.

Langkah-langkah yang dilakukan BPKAD untuk seluruh SKPD Kota Pekanbaru terkait sebagai tindak lanjut inventarisasi hingga nantinya dapat menyajikan data aset yang wajar pada penyusunan laporan keuangan Pemerintah Kota Pekanbaru Tahun 2015 adalah :

1. Pembentukan Tim Inventarisasi BMD Kota Pekanbaru Tahun 2015. Tim ini mencakup seluruh pihak yang terkait mulai dari Walikota Pekanbaru hingga Petugas Inventarisasi di unit-unit terkecil di SKPD Pengguna BMD;

2. Telah menyusun rancangan Perwako tentang SOP Pengelolaan BMD kepada Walikota Pekanbaru melalui bagian hukum Sekretaris Daerah Kota Pekanbaru;

3. Tetap melaksanakan kerjasama dengan pihak perwakilan BPKP Provinsi Riau untuk kelanjutan pelaksanaan inventarisasi BMD Kota Pekanbaru;

4. Melaksanakan kerjasama dengan pihak KPKNL (Kantor Pelayanan Kekayaan Negara dan Lelang) yang ditunjuk sebagai Tim Penilai Pengelolaan Barang Milik Daerah Kota Pekanbaru;
5. Telah melakukan Focus Group Discussion (FGD) dan pendampingan oleh pihak perwakilan BPKP Provinsi Riau dan Tim Inventarisasi BMD kota Pekanbaru mengenai kelanjutan inventarisasi pada beberapa SKPD yang dianggap belum dapat menyelesaikan inventarisasi dan menyajikan data asetnta secara wajar.

\subsection{Kendala Pelaksanaan}

\section{Sumber Daya Manusia}

Kurangnya sumber daya manusia yang berkualitas dan memiliki keahlian dalam hal pelaksanaan pembukuan, inventarisasi dan pelaporan aset tetap dan sumber daya manusia yang tidak sesuai antara jumlah pegawai yang ada dengan beban pekerjaan pelaksanaan penatausahaan aset tetap seperti di Dinas Pendidikan bagian pengelolaan asetnya dibantu 2 (dua) orang tenaga honorer untuk mengelola Gedung Sekolah TK 3 Gedung, Gedung Sekolah Dasar (SD) 194 Gedung, Gedung Sekolah SMP 40 Gedung, Gedung Sekolah SMA 16 gedung, Gedung Sekolah SMK 7 gedung, Gedung SKB 2 Gedung serta 10 UPTD. (Z.Bastian Kepala Bagian pengelolaan Aset Dinas Pendidikan).

2. Teknologi

Dalam melakukan pembukuan, inventarisasi dan pelaporan dibutuhkan perangkat berbasis teknologi sehingga lebih mempermudah untuk melaksanakan penatausahaan aset tetap. Pada Dinas Pendidikan Kota Pekanbaru teknologi yang digunakan masih manual yaitu dengan menggunakan exsel. (Z.Bastian Kepala Bagian Pengelolaan Aset Dinas Pendidikan).

3. Waktu

Keterbatasan waktu pelaksanaan inventaris yang hanya efektif selama 6 (enam) bulan yang diarasakan kurang maksimal.

4. Dokumen Pendukung

Setiap SKPD belum terbiasa dengan adanya Dokumen Pendukung untuk setiap aset tetap yang ada. Sehingga pada saat melakukan pembukuan, inventarisasi dan pelaporan jadi sulit menemukan dokumen 
aset tetap yang diperlukan tersebut. Seperti keterangan dari Bapak Ir. Dino Prima sebagai Kepala Bidang Aset Di BPKAD Kota Pekanbaru, kita terbiasa melakukan pembelian tetapi kita tidak terbiasa untuk membuat surat pendukung dan melakukan pembukuan.

5. Komitmen dari Pimpinan

Diperlukan komitmen pemimpin
untuk melaksanakan pembukuan, inventarisasi dan pelaporan. Pada Dinas Pendidikan diperlukan komitmen sekolah untuk tetap melaksanakan pembukuan, inventarisasi dan pelaporan

\section{PENUTUP}

\subsection{Kesimpulan}

Pada Analisis Pelaksanaan

Penatausahaan Aset Tetap Pada BPKAD

Kota Pekanbaru kesimpulannya adalah Pelaksanaan Penatausahaan Aset Tetap ada 3 (tiga) kegiatan yaitu Pembukuan, Inventarisasi dan Pelaporan.Pada Pembukuan dan Pelaporan sudah terlaksana dengan baik tetapi Inventarisasi belum terlaksana dengan baik karena tidak adanya pembuktian kertas kerja pada setiap aset.
BPKAD
Kota
Pekanbaru

merekapitulasi seluruh laporan yang diterima dari 44 (empat puluh empat) SKPD yang ada di kota Pekanbaru. Sedangkan Dinas Pendidikan adalah SKPD yang memiliki Aset yang terbanyak sehingga terlambat menyelesaikan laporan inventarisasinya karena belum selesainya setiap sekolah melakukan inventarisasi dan belum melaporkannya ke Dinas Pendidikan laporan inventarisasi itulah yang sering terlambat karena mindset menginventarisasi aset yang belum tinggi. Neraca sudah balance tapi pembuktian kertas kerja yang tidak bisa dibuktikan.

Kendala dalam Pelaksanaan

Penatausahaan Aset Tetap Pada BPKAD Kota Pekanbaru yaitu pertama, Sumber Daya Manusia yang tidak sesuai antara beban kerja dengan jumlah sumber daya manusia dan kurangnya sumber daya manusia yang memiliki keahlian di bidang pengelolaan aset, kedua Tekhnologi yang masih manual dengan menggunakan eksel, ketiga Keterbatasan waktu pelaksanaan Inventarisasi yang hanya efektif selam 6 (enam) bulan yang dirasakan kurang maksimal, keempat Dokumen Pendukung yang belum dapat dibutikan dan kelima Komitmen Pimpinan yang selalu komit tetap melaksanakan inventarisasi setiap tahunnya disertai dengan bukti kertas kerja dan sesuai antara laporan, neraca dan fisik

\subsection{Saran}

1. Meningkatkan Sumber Daya Manusia yang berkualitas dan mempunyai keahlian di bidang penatusahaan aset serta menambah jumlah sumber daya manusia baik untuk Di BPKAD Kota Pekanbaru maupun di Dinas Pendidikan Kota Pekanbaru.;

2. Disarankan setiap penerimaan aset baik melalui APBN atau APBD diinventarisasi kemudian dibuktikan dengan bukti kertas kerja dan dilaporkan jadi sesuai antara laporan, neraca dan fisik.

\section{DAFTAR PUSTAKA}

Mahmudi, 2010, Manajemen Keuangan Daerah, Jakarta : Erlangga

Yusuf, 20011, Langkah Pengelolaan Aset Daerah Menuju Pengelolaan Keuangan Daerah Menuju Pengelolaan Keuangan Daerah Terbaik, Jakarta : Salemba Empat

Peraturan Menteri Dalam Negeri No. 17 Tahun 2007 tentang Pengelolaan Barang Milik Daerah

Peraturan Daerah Kota Pekanbaru No. 14 Tahun 2008 tentang Pengelolaan Barang Milik Daerah

Peraturan Pemerintah No. 71 Tahun 2010 tentang Standar Akuntansi Pemerintah

Peraturan Daerah Kota Pekanbaru No. 19 Tahun 2016 tentang Pengelolaan Barang Milik Daerah. 